laryngeal nerve paralysis in a personal appeal to only three laryngologists in Britain, and concluded that many others must have remained undisclosed and undescribed. While the voice may be comparatively unaffected, the airway will always become obstructed. A permanent tracheostomy combined with a Negus speaking valve will provide an adequate airway and a normal speaking voice. Less drastic alternatives include Woodman's operation, ${ }^{14}$ which opens up the cords, providing an airway and eliminating any dyspnoea: the voice will be adequate in three-quarters of cases. ${ }^{15}$ Recently Tucker $^{16}$ has described a method of reinnervating the paralysed cord using a nerve-muscle pedicle; in five patients an adequate airway was obtained with no loss of voice.

1 Lahey, F H, Surgery, Gynecology and Obstetrics, 1944, 78, 239.

2 Riddell, V, British Fournal of Surgery, 1970, 57, 1. Till, A, ibid, p 9.

3 Wade, J S H, Proceedings of the Royal Society of Medicine, 1961, 54, 875.

4 Mountain, J C, Stewart, G R, and Colcock, B P, Surgery, Gynecology and Obstetrics, 1971, 133, 978.

5 Blomstedt, B, Acta Chirurgica Scandinavica, 1959-60, 118, 97.

6 Roy, A D, Gardiner, R H, and Niblock, W M, Lancet, 1956, 1, 988.

7 Beahrs, O H, and Vandertoll, D J, Surgery, Gynecology and Obstetrics, $1963,117,535$.

${ }^{8}$ Holt, G R, McMurry, G T, and Joseph, D J, Surgery, Gynecology and Obstetrics, 1977, 144, 567.

${ }^{9}$ Holl-Allen, R T J, Archives of Otolaryngology, 1967, 85, 335.

10 Wade, J S H, British fournal of Surgery, 1955, 43, 164.

11 Kratz, R C, Laryngoscope, 1973, 83, 59.

12 Rosswick, R P, Lancet, 1973, 1, 772.

${ }^{13}$ Moosman, D A, and DeWeese, M S, Surgery, Gynecology and Obstetrics, 1968, 127, 1011.

14 Woodman, De G, Archives of Otolaryngology, 1946, 43, 63.

15 Woodman, De G, Archives of Otolaryngology, 1953, 58, 150

16 Tucker, H M, Laryngoscope, 1976, 86. 769.

\section{Androgens in the anaemia of chronic renal failure}

We have now stopped searching so hard for methods other than transfusion to raise the haemoglobin concentration in patients with chronic renal failure. This has come about because of the finding that previous blood transfusion aids (probably by inducing immune unresponsiveness) rather than impairs the chances of subsequent survival of renal transplantation. Nevertheless, multiple transfusions in chronic renal failure still have two drawbacks: firstly, there is a risk of introducing hepatitis $B$ (or one of the non-B hepatitis viruses) into a renal dialysis unit; and, secondly, it is never easy to arrange transfusion for patients maintained on a home dialysis programme. Hence research into both the causes and treatment of the anaemia of chronic renal failure continues to be important.

The causes are multiple. Iron deficiency is common, especially in patients on maintenance haemodialysis, in whom excessive small blood losses in sampling and large losses into dialysis machines are important avoidable causes of anaemia. Folic acid is also lost in maintenance dialysis, and replacement of both this and iron is frequently required. The red blood cell membrane shows various transport abnormalities, mainly produced by humoral factors, and, though the decreased survival of red blood cells could be compensated for by a normal bone marrow, in chronic renal failure the marrow turnover is reduced.

Plasma erythropoietin concentrations are reduced or absent in anaemic uraemic patients, owing mainly to the reduction in functional renal mass. ${ }^{1}$ Advanced renal disease also affects the endocrine as well as the secretory function of the kidneys, ${ }^{2}$ and, because plasma erythropoietin concentrations are difficult to measure accurately, we do not know whether there is also some impaired responsiveness to available erythropoietin or whether plasma inhibitors to erythropoietin are present.

Treatment of the anaemia of renal failure should theoretically be aimed at stimulating endogenous production of erythropoietin; increasing marrow responsiveness to it; or identifying and isolating a substance with erythropoietin-like properties. ${ }^{3}$ For years androgens have been known to increase the rate of erythropoiesis; to raise the plasma erythropoietin concentrations of both anaemic and non-anaemic patients with intact kidneys; and to raise the haemoglobin concentrations of patients with chronic renal failure. Their action may mainly depend on increasing erythropoietin production from remnants of the kidneys. Certainly, studies in animals suggest that extrarenal sites of erythropoietin production are relatively unresponsive to the action of androgens ${ }^{4}$ - possibly an important factor in the timing of nephrectomy in patients on dialysis. Moreover, some drugs may also interfere with the action of testosterone. For example, its erythropoietic effect in female rats is almost completely abolished when these are pretreated with phenobarbitone ${ }^{5}-\mathrm{a}$ finding which if confirmed in man would have obvious practical importance.

Androgens have not been effective when used in patients with chronic renal failure not having maintenance dialysis. In those treated in this way, on the other hand, both the haemoglobin concentration and the packed cell volume (PCV) rose. This study was done in men given $300 \mathrm{mg}$ testosterone propionate per week who still retained their kidneys, but no response occurred in anephric patients. ${ }^{6}$ Shaldon et al $^{7}$ reported an improvement in haemoglobin even in anephric patients, but they used a bigger dose of testosterone $(500 \mathrm{mg} /$ week). Synthetic androgens have been used to try to avoid some of the complications of testosterone treatment. Nandrolone decanoate (Decadurabolin), which has to be given intramuscularly, was used in one double-blind trial, and raised both the haemoglobin concentration and the PCV. ${ }^{8}$ Oral synthetic androgens have also been tried. Eschbach and Adamson ${ }^{9}$ used fluoxymesterone with good haematological effect, though with less success in anephric patients; in a controlled trial oxymetholone failed to produce any benefit. ${ }^{10}$ Both these substances are C-17 methylated compounds, and may give rise to reversible liver damage, and will certainly make the patient more sensitive to concomitant warfarin treatment.

The other side effects of long-term androgen therapy may be important. Many men remark on improved sexual performance and increased muscle bulk, but priapism, occurring during sleep during dialysis, seems to be commoner and may result in permanent impotence. Problems in women include hirsutism, coarsening of the features, and acne. Haematomas are common at the injection site, especially since the injection is most conveniently given at the time of heparinisation for dialysis. Azotaemia may also suddenly increase after sudden withdrawal of androgens. ${ }^{11}$

Von Hartitzsch and his colleagues ${ }^{12}$ have recently argued for controlled trials of androgens for the anaemia of renal failure. In the meantime they suggest that androgens should be prescribed selectively for anaemic men on regular haemodialysis-a reasonable summary of the small place of these drugs in chronic renal failure.

\footnotetext{
1 Lancet, 1975, 1, 959.

2 DeGowin, R L, et al, Annals of Internal Medicine, 1970, 72, 913.

3 Naets, J P, Nephron, 1975, 14, 181.

4 Wang, F, and Fried, W, Fournal of Laboratory and Clinical Medicine, $1972,79,181$.
} 
${ }^{6}$ Resan, T K, Shahidi, N T, and Korst, D R, fournal of Laboratory and Clinical Medicine, 1972, 79, 187

' Fried, W, et al, Annals of Internal Medicine, 1973, 78, 527.

7 Shaldon, S, et al, British Medical fournal, 1971, 3, 212.

${ }^{8}$ Williams, J S, Stein, J H, and Ferris, T F, Archives of Internal Medicine, 1974, 134, 289.

${ }^{9}$ Eschbach, J W, and Adamson, J W, Annals of Internal Medicine, 1973, 78, 527.

10 Davies, M, et al, British fournal of Urology, 1972, 44, 387.

${ }^{11}$ Richardson, J R, and Weinstein, M B, Annals of Internal Medicine, 1970, 73, 403.

12 Hartitzsch, B von, et al, Nephron, 1977, 18, 13.

\section{Food and fibre}

Enthusiasm for fibre is sweeping the world. The journals are full of it, the popular press revels in it, and doctors take time off from prescribing it only to attend international conferences on it (Edinburgh 1973; Chicago 1974; Marabou, Sweden 1976; Washington 1977). A detached observer must be amused because the new craze is in fact one of the oldest inventions of nature. Fibre is simply plant cell walls. As such, it is the very basis of life on this planet, for only when cell walls evolved could plant life begin and hence, ultimately, animal life.

The natural diet of any plant-eating animal, including man, is obviously a fibre-rich diet. In "discovering" fibre modern man is waking up to the fact that his food is systematically deprived of fibre on its journey from field to grocery shop. A modicum of food processing is inevitable in urban civilisation, if only to keep food fresh, but food technology has recently developed a momentum of its own, and supermarket shelves are now crowded with highly contrived products. Almost all of these contain refined-that is, fibre-depleted-carbohydrate, especially sugar and white flour. Today most people get most of their carbohydrate in these forms. Consequently the average Briton obtains $18 \%$ of his daily calories from fibre-free sugar and about $20 \%$ from wheat flour that retains only a third of its original fibre.

Fibre is tough stuff, which is why it is removed. It is abundant in the outer layers of seeds, protecting the embryo within. Hence whole foods such as fruit and vegetables and unrefined cereals (wholemeal flour, brown rice, rolled oats, crude maize meal) have a rough texture in the mouth, and they have to be chewed. Chewing is work. This slows down the intake of food and may even deter it. Fibre-rich foods are probably digested and absorbed more slowly than refined foods, though experiments are needed to prove this. Certainly the extraction of water and electrolytes is delayed, ${ }^{12}$ thanks no doubt to the remarkable water-holding properties of fibre, ${ }^{3}$ and the contents of both small and large intestines are bulkier. ${ }^{1}$ The extra bulk would be expected to stimulate stretch receptors more and promote motor activity. But in fact the fibre-fed colon generates lower and less frequent pressure waves (at least in patients with initially high pressures-namely, those with diverticular disease and irritable bowel syndrome ${ }^{4-7}$ ), even though it transmits its contents more rapidly. Thus, fibre seems to make the motor work of the colon more efficient. It certainly makes defecation easier.

Cleave $^{8}$ saw that the same refining process which leads to underfilling of the colon and all its consequences leads also to overfilling of the mouth-that is, to overnutrition and all its consequences. The concept is so simple, and at the same time so big, that it is not easily accepted by academics trained in the complexities of biochemistry and the minutiae of cell biology. Furthermore, it is more respectable nowadays to solve problems by statistical tests than by logical argument.
The logic is hard to resist. Modern man has been lampooned as "fat, toothless, and constipated," and the statistics show that this is no exaggeration. Half the over-40s have only false teeth, ${ }^{9}$ half exceed $110 \%$ of ideal body weight, ${ }^{10}$ and most are on their way to diverticular disease. ${ }^{11}$ Nearly all eat almost all their carbohydrate in refined form. Since fibre dilutes calories and makes them harder to get, ${ }^{12}$ keeps the teeth clean and intact, and renders the stools soft, there is at least a case for the theory that fibre-depleted foods are intrinsically damaging to health.

It will take years of research to convict or acquit refined carbohydrates of all the charges laid against them. In the meantime, how much fibre should we eat to keep healthy ? It is an impossible question to answer. Even with traditional nutrients, the daily requirements are mostly disputed, arbitrary, or unknown. (For example, the energy requirements of similar subjects doing the same job may differ by $100 \%{ }^{13}$.) Fibre is not even a nutrient-it is the packaging that surrounds nutrients-so we can hardly apply the same rules. Moreover, it varies enormously, both qualitatively and quantitatively, in different plants, in the various parts of a plant, and at different ages of the plant. Can the requirements of such a variable dietary component be determined? The only practical way would be for the individual to adjust his intake of fibrecontaining foods until he obtained the desired effects. But even here there are problems. The desired effects of fibre are almost impossible to define numerically. Thus for stools we have no consensus on the ideal weight, frequency, consistency, and transit time. ${ }^{14}$ We do not know, and it is impracticable to measure, how quickly an individual should ingest and absorb his carbohydrate or how much chewing he should do to keep his mouth healthy. In the end research may produce some answers. For the moment there is something to be said for the simple view that if a man decides to take all his plant foods in unrefined form nature itself will ensure that his intake of fibre is right.

${ }^{1}$ McCance, R A, Prior, K M, and Widdowson, E M, British fournal of Nutrition, 1953, 7, 98.

2 Eastwood, M A, and Boyd, G S, Biochimica et Biophysica Acta, 1967, 137, 393

${ }^{3}$ McConnell, A A, Eastwood, M A, and Mitchell, W D, Fournal of the Science of Food and Agriculture, 1974, 25, 1457.

* Findlay, J M, et al, Lancet, 1974, 1, 146.

${ }^{5}$ Brodribb, A J M, and Humphreys, D M, British Medical fournal, 1976, $1,424$.

${ }^{6}$ Kirwan, W O, and Smith, A, Scandinavian fournal of Gastroenterology, $1977,12,331$.

${ }^{7}$ Manning, A P, et al, Lancet, 1976, 2, 394.

${ }^{8}$ Cleave, T L, The Saccharine Disease. Bristol, Wright, 1974.

${ }^{9}$ Hobdell, M H, Sheihani, A, and Slack, G L, British Dental fournal, 1969, 126, 349 .

10 Montegriffo, V M E, Postgraduate Medical fournal, 1971, June suppl, 418.

11 Parks, T G, Proceedings of the Royal Society of Medicine, 1968, 61, 932.

12 Heaton, K W, Lancet, 1973, 2, 1418 .

13 Garrow, J S, Energy Balance and Obesity in Man. Amsterdam, Associated Scientific Publishers, 1974.

14 Godding, E W, Lancet, 1976, 1, 1294.

\section{Mr Terence Millin}

Last week we inadvertently described $\mathrm{Mr}$ Terence Millin

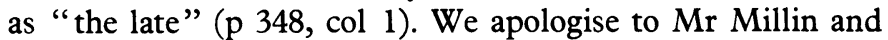
his family for any distress caused by the mistake, and we wish him long life and happiness at his home in County Wicklow.

As we go to press we regret to record the death of Lord Cohen of Birkenhead on 7 August. An obituary will appear in a later issue. 